\title{
Therapeutic Effects of Curcumin on Alzheimer's Disease
}

\author{
Edward C. Yao1, Lei Xue ${ }^{2}$ \\ ${ }^{1}$ lowa City West High School, lowa City, lowa, USA \\ ${ }^{2}$ Shanghai Key Laboratory of Signaling and Disease Research, School of Life Science and Technology, Tongji \\ University, Shanghai, China \\ Email: edwardcdy@gmail.com, lei.xue@tongji.edu.cn
}

Received 22 September 2014; revised 23 October 2014; accepted 7 November 2014

Academic Editor: Robin D. Couch, George Mason University, USA

Copyright (C) 2014 by authors and Scientific Research Publishing Inc.

This work is licensed under the Creative Commons Attribution International License (CC BY). http://creativecommons.org/licenses/by/4.0/

(c) (i) Open Access

\begin{abstract}
As the number of patients with Alzheimer's disease (AD) continues to rise throughout the twentyfirst century, scientists are increasingly looking for remedies, although the cause and pathology of the disease remain uncertain. Among treatments for $\mathrm{AD}$, there is a renewed interest in curcumin as a potential medication. Studies of the substance have found a large amount of consumption associated benefits, including anti-inflammatory and antioxidant effects. Its wide healing properties make it increasingly interesting to scientists, with potential uses in the treatment of cancers, arthritis, various cardiovascular diseases, and neurodegenerative diseases. More recently, curcumin has been shown to have multipotent effects against various symptoms of AD. Among other things, curcumin has been able to ameliorate toxicity of beta-amyloid species, a key part of AD nuerodegeneration, in vivo and in vitro, and has been able to inhibit multiple parts along suspected AD pathology. The goal of this review is to summarize the research done on curcumin with respect to its applicability as a treatment for $\mathrm{AD}$ and $\mathrm{AD}$ related pathology.
\end{abstract}

\section{Keywords}

Alzheimer's Disease, Curcumin, Beta-Amyloid

\section{Introduction}

Alzheimer's disease (AD), the most common form of dementia, affects one in nine Americans over the age of 65 [1]. As the population of the United States experiences a demographic shift towards older ages, the incidence 
of $\mathrm{AD}$ in 2050 is projected to double from that of 1995 [2]. As such, AD poses an increasingly large problemto the general population that remains to be fully explored.

In 1907, Alois Alzheimer first described a neurodegenerative condition he saw in a patient which would eventually become known as AD. He observed various insoluble plaques and death of brain cells in his patient's brain [3]. Later research proved that the fibrils were composed of beta-amyloid $(\mathrm{A} \beta)$ peptide, of which many of the peptides clumped up to form senile plaques which disrupted normal brain cell functioning [4]. The prevalence of $\mathrm{A} \beta$ plaques in $\mathrm{AD}$ patients and its neurotoxic effects thus make $\mathrm{A} \beta$ a likely candidate for a biomarker of the disease [5]. Though senile plaques remain a pathological hallmark of $\mathrm{AD}$, scientists found that soluble species of $\mathrm{A} \beta$ correlate more strongly to progressive levels of neurodegeneration [6]-[11]. Another central pathological indication of AD is formation of neurofibrillary tangles (NFT), caused by hyperphosphorylation of the tau protein [12] [13]. Originally supposed to stabilize microtubules, tau in its hyperphosphorylated state destabilizes microtubules, leading to inflammation within microglial cells and formation of NFTs, which trigger cell death [14].

\section{Curcumin and Its Properties}

Curcumin is derived from the herb Curcuma Longa, more commonly known as turmeric, a sterile plant. Formally identified as diferuloylmethane, curcumin was first classified in 1815, and its crystalline form was first obtained in 1870. For centuries, it was frequently used as a natural plant product in Ayurveda, an Indian system of holistic medicine, to treat inflammation, liver disorders, diabetic wounds, and Sinusitis. Its usage has now expanded beyond medicinal purposes to many products and substances across the world, including curry, mustard, band-aids, cheese, and butter [11].

Curcumin is a substance that is sensitive to degradation by visible and ultraviolet light, as well as high $\mathrm{pH}$ and oxygen, having a half-life of around 8 hours in human blood [15]. The structure of curcumin is largely composed of a carbon chain linking two aryl groups. Researchers have found the phenolic $\mathrm{OH}$ groups attached to the aryl groups to be able to scavenge reactive oxygen species (ROS), contributing to its anti-oxidative effect. Additionally, curcumin was shown to interact with many different substances including DNA, lipids, and proteins [16].

The increasing amount of literature over Curcumin indicates versatile applications of Curcumin's properties. Curcumin has been shown to inhibit multiple pathways involved in apoptosis and cell invasion, exerts potent anti-oxidant effects, and affects enzymes that control tumor activity [17] [18]. Indeed, research has been done on the effects of curcumin for various medical uses, and scientists have found potential roles of curcumin in inhibition of invasion by thyroid cancer cells, exertion of protective effects against alcohol induced toxicity, and prevention of breast cancer, among other uses [19]-[22].

\section{Alzheimer's Disease and Curcumin}

A cross-cultural study of India and the United States found that the Indian population aged $70-79$ had a 4.4 time lower prevalence of AD compared to the same population in the United States [23]. Researchers attributed part of the lower incidence of AD to the increased consumption of curry, and thus curcumin. To further verify this, a study found improved cognitive function among populations that consume curry, a food containing curcumin, on a regular basis than those who don't [24]. Additionally, research conducted on the ability of curcumin to scavenge free radicals has shown that it is able to outperform vitamin E ( $\alpha$-tocopherol) and tetrahydrocurcu$\min [25]$ [26]. Once initial studies established the relationship between curcumin and a lower incidence of AD, others sought to elucidate the mechanisms whereby curcumin could interact with $\mathrm{AD}$ [27] [28].

Particularly important to scientists studying the connection between curcumin and AD is the blood-brain-barrier (BBB), a highly protective reticulum which molecules must be able to cross to effectively reach the brain [29]. Curcumin was shown to be able to cross the BBBprimarily because of its hydrophobic properties [29] [30]. In fact, curcumin has also been shown in vivo to even prevent disruption and degradation of the BBB by preventing damage from $\mathrm{ONOO}^{-}[30]$. In the presence of $\mathrm{A} \beta$, curcumin showed a significant red shifted absorbance spectrum, proving that $\mathrm{A} \beta$ binds curcumin and impedes curcumin's degradation [31]. Taken together, these results suggest that curcumin may be able to serve as an indicator of Alzheimer's disease by identifying A $\beta$ plaques. 


\subsection{A $\beta$ Inhibition}

The amyloid precursor protein (APP) can be cleaved by multiple enzymes (Figure 1). In contrast to normal cleavage by $\alpha$-secretase and $\gamma$-secretase, when APP is cleaved by BACE 1 and subsequently $\gamma$-secretase beta amyloid is produced, along with the APP intracellular domain fragment and the $\operatorname{SAPP} \beta$ fragment. A $\beta$ may be cleaved into different lengths, the most common being 40 amino acids and 42 amino acids long, the latter one displaying less solubility. Initially, neurodegeneration was thought to have been caused by the formation of senile plaques described by Alois Alzheimer [3]. This was supported by research that found that $\mathrm{A} \beta$ in its fibrillar form (A $\beta \mathrm{f})$, the form which forms senile plaques, can trigger various neurotoxic effects, such as tau hyperphosphorylation [2]. However, later research done on $\mathrm{A} \beta$ indicated that its soluble oligomer form (A $\beta 40)$ correlated more closely with the severity of symptoms shown, leading to suspicion that the soluble species of $\mathrm{A} \beta$ in fact mediated toxicity [32] [34] [35]. Studies have indicated soluble $\mathrm{A} \beta$ to be attracted by copper and zinc ions at synapses, and some have hypothesized that its affinity for such metal ions near the synapses are responsible for its toxicity at receptor sites [36]. Others have explored concentrations of soluble $\mathrm{A} \beta$ gradually eroding mitochondrial activity as a possible cause of the AD cascade [32]. Accordingly, many developed and developing AD therapies have been targeting $\mathrm{A} \beta$ plaques, oligomers, and fibrils including immunotherapies, pharmacological treatments, and passive and active vaccines [37]-[39].

Like these treatments and therapies, curcumin has the potential to inhibit formations of $\mathrm{A} \beta$ plaques and lower soluble $\mathrm{A} \beta$ levels, suggesting a similar mechanism. When fed in low doses to $\mathrm{APP}^{\text {swe }}$ mice (mice with the Swedish mutant APP transgene), curcumin displayed an ability to significantly decrease soluble and insoluble A $\beta$ levels compared to mice who were fed high doses of curcumin or not fed curcumin at all. Both oxidative damage and plaque burden were reduced in mice who had received the curcumin treatment versus those that didn't. Interestingly, the size of individual plaques in treated mice was found to be reduced as well, but the reduction in size wasn't statistically significant $[40]$. A later study on $\mathrm{APP}^{\mathrm{swe}} / \mathrm{PS}^{\mathrm{dE} 9}$ mice observed that curcumin was able to prevent the formation of new $\mathrm{A} \beta$ plaques and remove preexisting plaques. However, even while reducing the prevalence of $\mathrm{A} \beta$ plaques, curcumin increased the ratio of soluble $\mathrm{A} \beta 42$ to soluble $\mathrm{A} \beta 40$, thought to positively correlate with presence of $\mathrm{AD}$ [41]. Curcumin has also been investigated in multiple studies using a Drosophila

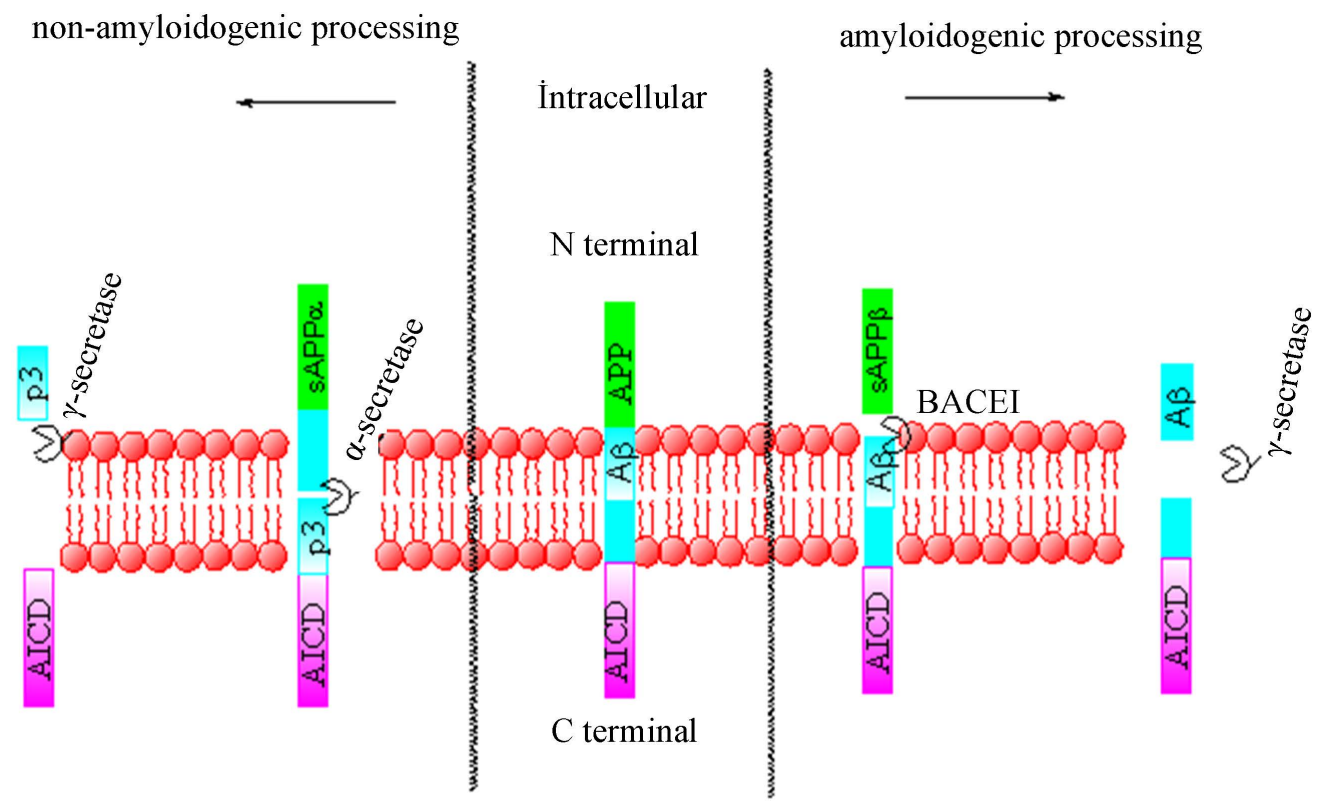

İntercellular

Figure 1. Amyloidogenic and non-amyloidogenic processing of APP produce different products. Amyloidogenic processing results in BACE1 cleaving sAPP $\beta$ and subsequent intracellular release of $\mathrm{A} \beta$ and intercellular release of AICD after cleavage by $\gamma$-secretase. Non-amyloidogenic processing results in cleavage of sAPP $\alpha$ by $\alpha$-secretase, and release of p3 intracellularly and AICD intercellularly after cleavage by $\gamma$ secretase. 
model of AD. Scientists found a positive effect of curcumin on lifespan and activity of flies carrying A $\beta 1-40$, $\mathrm{A} \beta 1-42$, and $\mathrm{A} \beta 1-42^{\mathrm{E} 22 \mathrm{G}}$ lines [42]. Using a different transgene, another group was able to show that several derivatives of curcumin, including diarylalkyls curcumin, demethoxycurcumin, and bisdemethoxycurcumin, were able to rescue morphological defects in the eyes of GMR $>$ APP/BACE-1 expressing flies. Drosophila expressing elav > APP/BACE-1 and elav > BACE-1 also showed significant improvement in locomotor activity through a climbing assay and significant lengthening of lifespan [43]. In contrast to the study in mice, however, curcumin treated Drosophila displayed no change in soluble A $\beta$ ratios [31]. It is suggested that one of the ways by which curcumin decreases production of $\mathrm{A} \beta$ is through downregulation and phosphorylation of the enzyme GSK-3 $\beta$, which is thought to decrease presenilin- 1 and $\gamma$-secretase activity [43].

An in vitro study of the effect of curcumin on $\mathrm{A} \beta$ peptides showed that its presence tends to destabilize the $\beta$-sheet formation of $\mathrm{A} \beta$. This could be due to the hydrophobic nature of curcumin disturbing the attractions necessary for formation of $\beta$-sheet structures, or $\pi-\pi$ interactions between the keto or enol rings of curcumin and the aromatic characteristic of $\mathrm{A} \beta$ dimers [41]. A "Goldie-locks" model has been proposed to describe curcumin's interaction with $\mathrm{A} \beta$ (Figure 2). Curcumin appears to be a good match for activity with $\mathrm{A} \beta$, given its hydroxyl substitution on itsaromatic groups and its relatively inflexible linker between the two aromatic groups [44]. Further evidence that curcumin binds at the 12th and $17-21$ st residues of $\mathrm{A} \beta_{42}$ and this binding seems not to be site-specific suggests that curcumin interacts with intermolecular $\beta$-sheet binding [45].

\subsection{Curcumin and Macrophages}

A different interaction between curcumin and $\mathrm{A} \beta$ plaques lies in the interaction between curcumin and macrophages. Macrophages are thought to play a role in the body's innate ability to inhibit $\mathrm{A} \beta$ plaques by inducing phagocytosis of $\mathrm{A} \beta$ through innate immunity or an adaptive immune system. In $\mathrm{AD}$ patients, however, it is postulated that these macrophages are less effective at clearing $\mathrm{A} \beta$ peptides than those of healthy individuals [46]. A likely explanation for this decreased efficiency is that $\mathrm{AD}$ patients have greater immune tolerance for $\mathrm{A} \beta$, which hinders the innate immune response to $\mathrm{A} \beta$ plaque formation [47]. However, introduced antibodies responding to $\mathrm{A} \beta$ were able to reduce the $\mathrm{AD}$ pathology in a mouse model, providing hope for methods targeting phagocytosis of $\mathrm{A} \beta$ [48]. An in vitro study done on human macrophages have shown that treating them with curcumin increases their $\mathrm{A} \beta$ uptake and causes intracellular phagocytosis of $\mathrm{A} \beta$ as well [49]. Thus, curcumin may inhibit $\mathrm{A} \beta$ plaque formation indirectly as well through macrophages.

\subsection{Cholesterol and Curcumin}

Another suggested mechanism through which curcumin is able to alleviate the inflammatory cascade is its interactions with cholesterol. High plasma cholesterol levels were shown to have a strong connection with $\mathrm{A} \beta$ generation through multiple animal models, possibly up-regulating the production of $\mathrm{A} \beta$ [50]. Cholesterol also shows a relationship to the ApoE gene, which has been linked to the late-onset form of $\mathrm{AD}$ [9]. The opposite

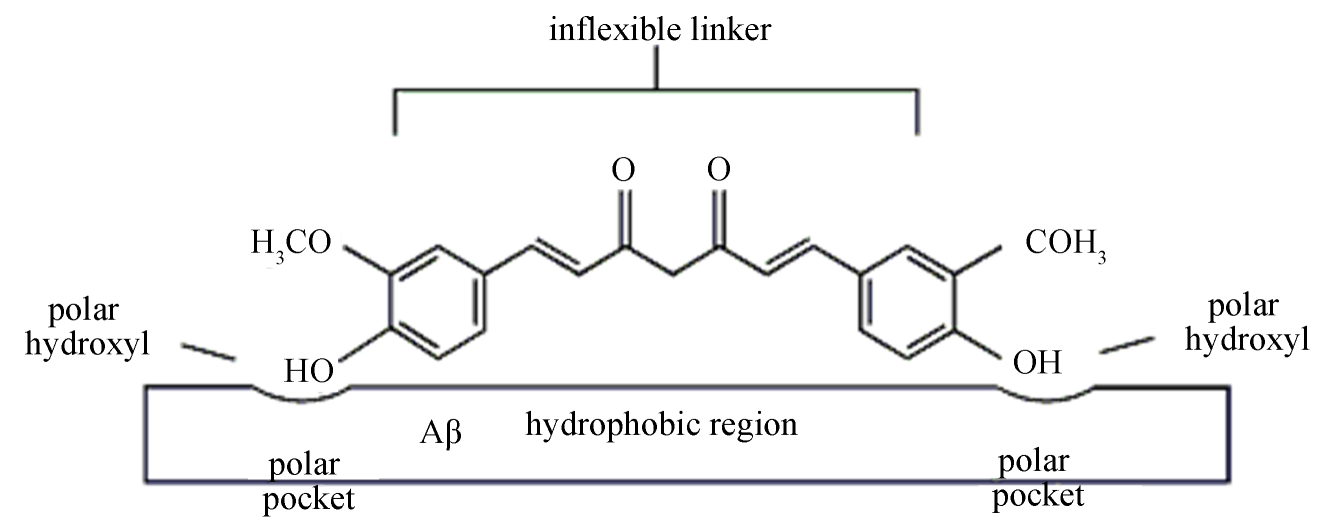

Figure 2. Curcumin's polar hydroxyl groups attached to its aromatic groups interact with the polar pockets of the $\mathrm{A} \beta$ protein, making it apt to destabilize certain $\beta$-sheets. Its inflexible linker between the two aromatic groups contribute to this binding property. 
was also found in an experiment on C. elegans: reducing cholesterol supply alleviated symptoms of paralysis caused by $\mathrm{A} \beta$ [51]. Along with high levels of metal ions of copper, iron, and zinc, cholesterol was extensively researched to elucidate its role in $\mathrm{AD}$ pathogenesis [52].

Though a relationship between cholesterol and AD has been established, specific mechanisms on the interaction between the two have been sparse. One theory indicates that cholesterol rich microdomains, notably lipid rafts, display a much higher level of $\gamma$-secretase and possibly $\beta$-secretase, and therefore the localization of APP to these membranes. Due to decreased activity of $\alpha$-secretase and an increased $\beta$-secretase activity in the presence of lipid rafts, cholesterol is thought to promote amyloidogenic processing of APP [53] [54]. Confirming this relationship in animals, research has been conducted showing high cholesterol to increase sAPP production [55]. However, evidence in human AD patients has been far less conclusive [56]. For example, AD patients had higher levels of 24-hydroxycholesterol (24-OH), a cholesterol oxidation product created by the oxidase CYP46A1 that is able to cross the BBB easily, but displayed reduced plasma levels of $24-\mathrm{OH}$ as the disease progressed. This may be explained by the higher level of 27-hydroxycholesterol (27-OH), oxidized by CYP27A1, which has led researchers to think of $\mathrm{AD}$ not relating to overall cholesterol levels, but as a product of a different ratio of 24-OH to 27-OH [57] [58]. Others have viewed imbalances in cholesterol as a product of disruption of the Golgi apparatuscholesterol trafficking by $\mathrm{A} \beta$ [59]. Yet others have proposed cholesterol's modification of gangliosides, particularly GM1, as increasing the ability of $\mathrm{A} \beta$ to congregate from predominantly $\alpha$-helixes to more $\beta$-sheets [60].

A study in humans found that curcumin increased HDL cholesterol levels and decreased overall cholesterol levels [61]. Accordingly, a reduction in overall cholesterol would be able to mitigate amyloidogenic processing of APP and reduce overall A $\beta$ plaque burden [62]. Whether curcumin, in fact, does lower serum levels of cholesterol is still debated. Multiple studies have found curcumin to have no significant effect on cholesterol levels, though these contradictory results were carried out on different animal models and thus were possibly subject to different cholesterol metabolism mechanisms [63].

\subsection{Curcumin and Metal Ions}

Several metal ions play key roles in the pathogenesis of AD. The most studied metal ion is copper $\left(\mathrm{Cu}^{++}\right)$. A close link has been established between AD and copper. APP knockout mice displayed an increase in copper levels in the brain and liver while in humans, senile plaques display high concentrations of copper [64]-[66]. In fact, some have even gone as far as hypothesizing inorganic copper as a leading cause of AD in developed countries [67].

Though the importance of copper to neurological degradation of $\mathrm{AD}$ is generally agreed upon, the mechanism by which it does so remains unclear. BACE1, the most crucial form of $\beta$-secretase involved A $\beta$ cleavage of APP, has been shown to interact with copper ions, suggesting a possible role of copper in regulation of APP processing [58] [68]. A diet supplemented with copper resulted in more A $\beta$ aggregation and senile plaque like structures in rabbits, possibly through this $\beta$-secretase mechanism [69]. In vivo studies have hinted at another mechanism by which copper can exert effects: increased copper has been found to directly interact with $\mathrm{A} \beta$ penetration of the lipid bilayer, allowing $\mathrm{A} \beta$ penetration at lower $\mathrm{pHs}$ [70]. Perhaps another way copper interacts with $\mathrm{AD}$ is by causingmore lipid peroxidation and $\mathrm{A} \beta$ fibril formation when the Copper- $\mathrm{A} \beta$ complex produces hydroxynonenal, which modifies the His residue on A $\beta$ [71] [72]. Similarly to cholesterol, copper has been suggested to elevate $\mathrm{A} \beta$ levels in lipid rafts [73]. Increased levels of copper may also affect the functioning of lowdensity lipoprotein receptor-related protein 1 , which removes $\mathrm{A} \beta$ across the $\mathrm{BBB}$, much like macrophages [74].

Evidence has also been found that human $\mathrm{A} \beta$, though interestingly not rat $\mathrm{A} \beta$, generates ROS in the presence of $\mathrm{Fe}(\mathrm{III})$ and $\mathrm{Cu}(\mathrm{II})$ [75]. AD may additionally upregulate calcium signaling, which may account for the declines in memory [76] [77].

Studies carried out on clioquinol, a $\mathrm{Cu} / \mathrm{Zn}$ chelator, have shown that it is able to decrease $\mathrm{A} \beta$ deposition. In transgenic APP mice, treatment over 9 weeks with clioquinol reversed copper and zinc induced $\mathrm{A} \beta$ aggregation [78]. Similarly, other metal chelators have been shown to have an inhibitory effect on $\mathrm{A} \beta$ aggregation and ROS generation [79] [80]. A yeast model of $\mathrm{A} \beta$ expression also found degradation of metal-dependent $\mathrm{A} \beta$ oligomers, further supporting a possible role of metal chelation in the cure for AD [81]. A Drosophila model using GMRGal4 to drive transgenic $\mathrm{A} \beta$ expression also showed that presence of metal chelators is able to reduce $\mathrm{A} \beta$ phenotype in Drosophila eyes [82]. 
Since curcumin is a chelator of iron and copper, metal chelation could be one mechanism that prevents $\mathrm{A} \beta$ aggregation, similar to clioquinol [30] [83]. Curcumin indeed shows the ability to chelate copper with $\mathrm{A} \beta$ peptides present, making this hypothesis even more plausible [84]. However, curcumin's effect on $\mathrm{A} \beta$ toxicity through copper seems to be dose-dependent, because curcumin fed at higher concentrations increased production of free radicals from copper in an in vitro study [85]. Similarly to copper, curcumin was also able to significantly lower the extracellular concentration of calcium, potentially downregulating the increased calcium signaling associated with $\mathrm{AD}$ and thus blocking apoptosis [86].

In contrast to initial findings, however, mice overexpressing $\mathrm{APP}^{\text {swe }}$ displayed significantly lower amounts of soluble $\mathrm{A} \beta$ after receiving a diet supplemented by copper [87]. Hence, $\mathrm{AD}$ is also suggested to be caused by a deficiency of copper, pointing out that many AD symptoms are consistent with a lack of copper [88]. Another study agrees with this, showing increased production of APP and thus $\mathrm{A} \beta$ and slower degradation of $\mathrm{A} \beta$ in the presence of a copper deficiency [89]. If that is the case, then curcumin may have in fact increase A $\beta$ toxicity by reducing levels of copper.

\subsection{Cytokines and Curcumin}

Escalatory AD pathology results in increased apoptosis in brain cells compared to non-AD brain [90]. Elevated levels of interleukin-1, an inflammatory cytokine, have been shown to increase expression of APP, likely leading to $\mathrm{A} \beta$ accumulation [91]-[93]. Generally, inflammation blocking drugs have been somewhat effective in alleviating symptoms of $\mathrm{AD}$, pointing to a potential role of blocking cellular signaling as a prospective mechanism for AD mitigation. Nonsteroidal anti-inflammatory drugs (NSAIDS) like ibuprofen have been able to reduce levels of soluble $\mathrm{A} \beta$ in transgenic $\mathrm{Tg} 2576$ mice, possibly through inhibition of inflammatory cytokines like interleukin-1 beta (IL-1 $\beta$ ) and transforming growth factor- $\beta$ [93]. In human AD brains, higher levels of IL- $1 \alpha$ have been linked to the evolution of AD pathology and processing of APP [94]-[96]. Even though there is a weak connection between cox-2 and $\mathrm{AD}$, multiple studies done on selective cycloxygenase-2(COX-2) inhibitors have shown increases in $\mathrm{A} \beta 42$ levels [97].

Curcumin also interacts with various inflammatory cytokines, thus potentially reducing the extent of the inflammatory cascade triggered by $\mathrm{A} \beta$. In one study carried out on chondrosarcoma cells, curcumin has been found to inhibit interleukin-1 signaling [98]. However, a study carried out on AD rats found no effect from curcumin on IL- $1 \beta$, but did find an inhibitory effect from demethoxycurcumin, a close relative to curcumin in the curcumnoid family [99]. Additionally, it was found that curcumin upregulated expression of COX-2 [100]. Curcumin also displays the ability to raise the lowered levels of Akt and inhibit the activation of capasce-3 caused by intracellular $\mathrm{A} \beta$, which are both closely linked to apoptotic processes [101].

\subsection{Curcumin as a Free Radical Scavenger}

Critical to AD pathology and inflammation responses is the excessive generation of free radicals. It has been suggested that $\mathrm{A} \beta$ toxicity is closely related to cell membranes' interactions with these free radicals species [101]. Specifically, $A \beta$ is thought to induce lipid peroxidation in these membranes, which would interfere with specific protein functions and result in cell death [102]. Brain cells are more susceptible to oxidative damage than other cells in the body because they mainly use glucose and digestion of glucose requires use of ROS, while they also have less enzymatic defense against oxidative stress [103]. Indeed, prefrontal cortex cells taken from AD patients showed high percentages of oxidized mRNA, likely due to these mechanisms [104]. Independently, in vitro studies have shown that this toxicity may be due to small segments of the $\mathrm{A} \beta$ peptide, and not necessarily due to the full length APP protein [105]. In a study carried out on PC12 cells, curcumin pretreatment of cells inhibited A $\beta$ induced cytotoxicity [106]. In a mouse model, SOD activity was significantly decreased after mice were treated with curcumin, suggested antioxidant capabilities of curcumin [107]. When compared to other standard antioxidants, curcumin was found to have free-radical scavenging properties similar to $\alpha$-tocopherol, BHA, and BHT [25]. An in vitro study in rat cortical neuron cells found that curcumin displayed a strong ability to scavenge the super oxygen anion radical, being four times more effective than a known scavenger trolox [107]. As mentioned before, these properties are attributed to the phenolic $\mathrm{OH}$ group attached to the two methoxy groups, which are able to transfer hydrogen atoms or sequentially transfer an electron and proton $[16]$. 


\section{Tau}

Recent findings have increasingly pointed towards tau, part of a family of microtubule-associated proteins, as involved in AD pathogenesis [14] [108]. Though tau aggregation independently has been shown to cause NFTs because of its microtubule related activities, neurotoxicity occurs before NFTs form from hyperphosphorylated tau. This suggests that soluble species of tau may be the driver behind the inflammatory cascade, and points away loss-of-function or gain-of-function theories of tau neurotoxicity [109] [110]. Though A $\beta$ and tau are able to exert toxicity from different mechanisms, $\mathrm{A} \beta$ has been shown to interact with tau, suggesting a synergetic pathology between the two molecules [111]. An experiment conducted on the role of tau showed a lack of neuronal loss in tau-knockout mice neurons compared to those non-knockout and transgenic human tau expressing mice [112]. Tau has been suggested to mediate toxicity from $\mathrm{A} \beta$ through its interactions with fyn, a protein kinase that reduces hyperactivity of NMDA receptors. Because an increased level of tau and fyn, and therefore upregulated NMDA receptor activity, accompany AD, dendrites are exposed to high concentrations of calcium, causing neuron death. Knockout tau mice, on the other hand, showed reduced dendritic fyn [113].

Therapies have been developed that target tau kinases to reduce the amount of hypersphosphorylation, targeting kinases such as GSK-3 $\beta$ [114]. Curcumin was found to bind to NFTs in multiple animals, albeit displaying a weaker binding than to $\mathrm{A} \beta$, raising the possibility of serving as an identifier [115]. Nueroblastoma cells displayed lower levels of tau overall and of phosphorylation at the serines at 262 and 396 after being treated with curcumin [116]. However, a similar study on PC12 cells showed that levels of tau were unchanged after curcumin treatment, while levels of phosphorylated tau were also decreased [86]. A suggested mechanism by which tau does this is through upregulation of the cochaperone BAG2 protein, which can clear tau tangles from cells [10]. With regards to the interaction between fyn and tau, curcumin has been shown to reduce the deficiency of NMDA receptors, as well as reduce the levels of soluble tau in transgenic AD mice, correcting behavioral deficits [117].

\section{Clinical Trials and Bioavailability}

Curcumin displays very poor bioavailability in both human and mice, as levels of curcumin in the blood plasma have been very low compared to dosages, indicating poor absorption capability [117]. Its insolubility in water makes it challenging to administer, and its short half-life makes it ineffective over longer periods of time should it reach the bloodstream [118].

Researchers have tested various modes of administration, the most common being oral dosages administered to humans and animals. Other means of administration include intraperitoneal injection as well as intravenal delivery, more commonly seen in animal model testing [119]. Indeed, rats orally ingesting curcumin showed just $1 \%$ bioavailability compared to intravenous injections, which showed much higher levels of bioavailability [120]. In order to make curcumin more effective, different modes of administration have been researched. Studies have found that curcumin administered through dry emulsions, lauroyl sulphated chitosan, and flexible liposomes, among others, reach higher absorption and maximum concentrations [121]-[123].

The metabolism of curcumin may provide an answer to why bioavailability is so low in oral dosages. Studies have shown that in curcumin, depending on the administration method, is metabolically O-conjugated into curcumin gluconeride and sulfate, or produce tetrahydrocurcumin, hexahydrocurcuminol, and hexahydrocurcuminol through bioreduction (Figure 3). This is observedin mice in vivo and human and rat hepatocytes [120] [124] [125]. Additionally, some of these compounds are weaker in their effects than curcumin. For example, hexahydrocurcuminol and octahydrocurcumin have reduced abilities to suppress COX-2 and NF- $\mathrm{B}$, respectively [126] [127]. This would help to explain the discrepancy between expected results and actual results of curcumin testing on humans.

Thus far, few clinical trials of curcumin with respect to AD have been completed. Baum et al. completed a 6 month clinical trial on AD patients and curcumin, and found no significant difference between curcumin receiving patients and placebo receiving ones. Additionally, no difference in absorption was detected between the $1 \mathrm{~g}$ dose receiving patients and the $4 \mathrm{~g}$ receiving patients, which suggests that curcumin has a maximum efficacy [128]. Ringman et al. completed a 24-week long double blind study on curcumin's effect on AD, and found no significant differences between the experimental groups ( $2 \mathrm{~g}$ or $4 \mathrm{~g}$ per day) and the placebo group in terms of MMSE and ADAS-Cog tests [129]. As noted, curcumin showed very low concentrations in the blood plasma after dosage, lining up with earlier predictions about bioavailability. Though several patients displayed adverse 


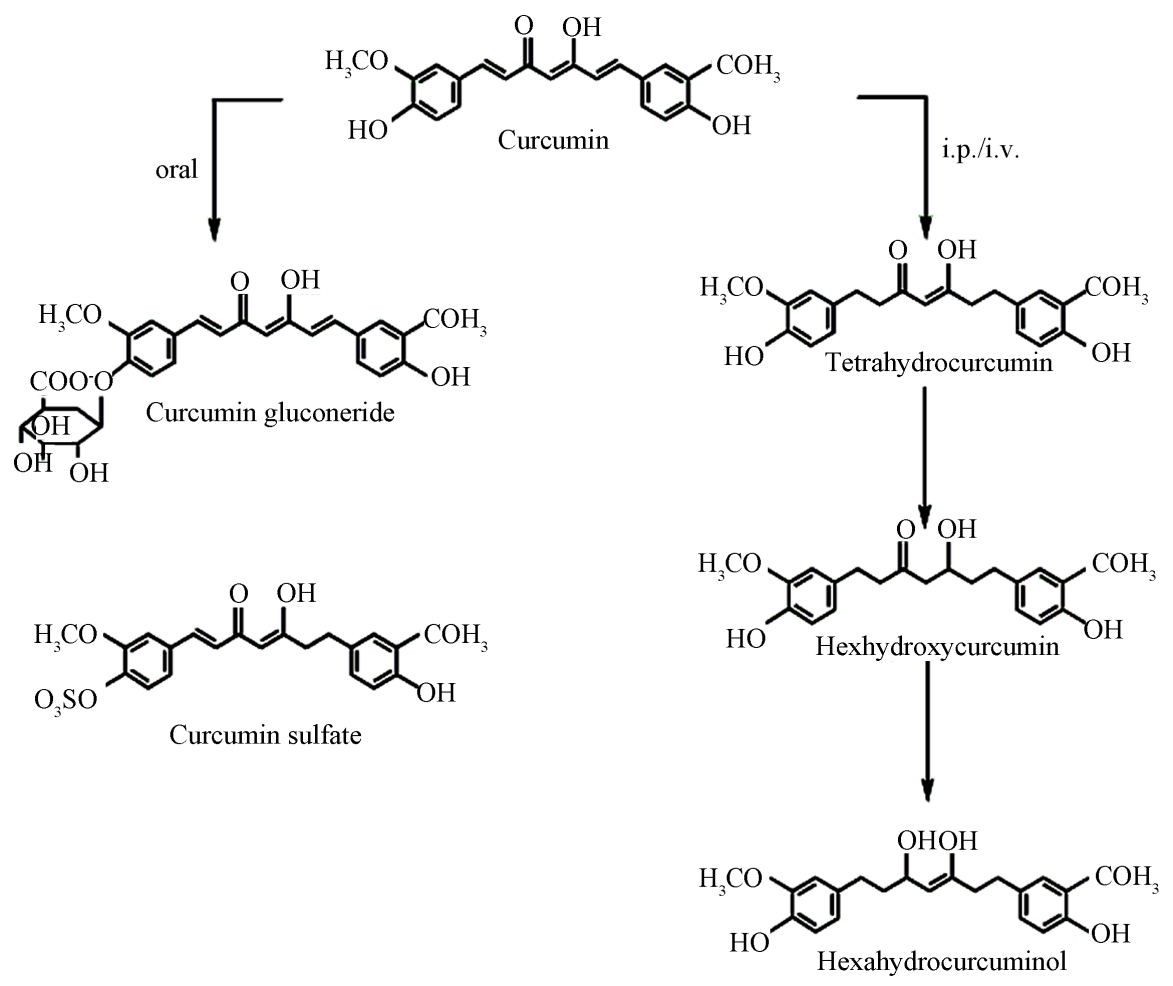

Figure 3. Metabolism of curcumin depends on the administration method. Intraperitoneal or intravenal administration results in tetrahydrocurcumin, hexhydroxycurcumin, and hexahydrocurcuminol, where as oral administration results in curcumin gluconeride and Curcumin sulfate.

symptoms from administration in Ringman et al.'s study, other studies in humans have suggested a tendency towards fewer side effects with increasing curcumin dosage (up to $4 \mathrm{~g}$ ), suggesting that it is safe for consumption and treatment [130].

\section{Conclusion}

With the proliferation of literature and study on curcumin, new connections are being made to AD. Curcumin has shown an ability to destabilize $\mathrm{A} \beta$ plaque formation, increase phagocytosis of $\mathrm{A} \beta$, interact with metal ions and cholesterol, and reduce overall inflammation from escalatory pathology due to tau. Curcumin also shows the potential to inhibit COX-2 and NF- $\kappa \mathrm{B}$ activity, reducing overall inflammation. Compared to other substances, curcumin shows a potential to treat $\mathrm{AD}$ through multiple methods, offering diverse applications and wider usage, while remaining overwhelmingly safe with little to no side effects in animal models and clinical trials. However, the key hurdle between potential uses and clinical efficacy is the problem of bioavailability, which has yet to be sufficiently solved. Future research should focus on methods to increase bioavailability when administered to humans to fully explore potential similarities and thus anti-AD effects of curcumin as a potential treatment for the disease.

\section{Acknowledgements}

This study was supported by Shanghai Committee of Science and Technology (grant No. 09DZ2260100, 14JC1406000).

\section{References}

[1] Alzheimer's Association (2014) Alzheimer's Disease Facts and Figures. Alzheimer's \& Dementia: The Journal of the Alzheimer's Association, 10, e47-e92. http://dx.doi.org/10.1016/j.jalz.2014.02.001

[2] Hebert, L.E., Beckett, L.A., Scherr, P.A. and Evans, D.A. (2001) Annual Incidence of Alzheimer Disease in the United 
States Projected to the Years 2000 through 2050. Alzheimer Disease and Associated Disorders, 15, 169-173. http://dx.doi.org/10.1097/00002093-200110000-00002

[3] Alzheimer, A., Stelzmann, R.A., Schnitzlein, H.N. and Murtagh, F.R. (1995) An English Translation of Alzheimer's 1907 Paper, Uber eine eigenartige Erkankung der Hirnrinde. Clinical Anatomy, 8, 429-431. http://dx.doi.org/10.1002/ca.980080612

[4] Lorenzo, A. and Yankner, B.A. (1994) Beta-Amyloid Neurotoxicity Requires Fibril Formation and Is Inhibited by Congo Red. Proceedings of the National Academy of Sciences of the United States of America, 91, 12243-12247. http://dx.doi.org/10.1073/pnas.91.25.12243

[5] Zetterberg, H., Blennow, K. and Hanse, E. (2010) Amyloid Beta and APP as Biomarkers for Alzheimer's Disease. Experimental Gerontolog, 45, 23-29. http://dx.doi.org/10.1016/j.exger.2009.08.002

[6] Shankar, G.M., Li, S., Mehta, T.H., Garcia-Munoz, A., Shepardson, N.E., Smith, I., et al. (2008) Amyloid-Beta Protein Dimers Isolated Directly from Alzheimer's Brains Impair Synaptic Plasticity and Memory. Nature Medicine, 14, 837842. Http://Dx.Doi.Org/10.1038/Nm1782

[7] Broersen, K., Rousseau, F. and Schymkowitz, J. (2010) The Culprit behind Amyloid Beta Peptide Related Neurotoxicity in Alzheimer's Disease: Oligomer Size or Conformation? Alzheimer's Research \& Therapy, $2,12$. http://dx.doi.org/10.1186/alzrt36

[8] McLean, C.A., Cherny, R.A., Fraser, F.W., Fuller, S.J., Smith, M.J., Beyreuther, K., Bush, A.I. and Masters, D.L. (1999) Soluble Pool of Abeta Amyloid as a Determinant of Severity of Neurodegeneration in Alzheimer's Disease. Annals of Neurology, 46, 860-866. http://dx.doi.org/10.1002/1531-8249(199912)46:6<860::AID-ANA8>3.0.CO;2-M

[9] Walsh, D.M., Klyubin, I., Fadeeva, J.V., Cullen, W.K., Anwyl, R., Wolfe, M.S., et al. (2002) Naturally Secreted Oligomers of Amyloid Beta Protein Potently Inhibit Hippocampal Long-Term Potentiation in Vivo. Nature, 416, 535-539. http://dx.doi.org/10.1038/416535a

[10] Yankner, B.A. (1996) Mechanisms of Neuronal Degeneration in Alzheimer's Disease. Neuron, 16, 921-932. http://dx.doi.org/10.1016/S0896-6273(00)80115-4

[11] Goel, A., Kunnumakkara, A.B. and Aggarwal, B.B. (2008) Curcumin as "Curecumin": From Kitchen to Clinic. Biochemical Pharmacology, 75, 787-809. http://dx.doi.org/10.1016/j.bcp.2007.08.016

[12] Mohandas, E., Rajmohan, V. and Raghunath, B. (2009) Neurobiology of Alzheimer's Disease. Indian Journal of Psychiatry, 51, 55-61. http://dx.doi.org/10.4103/0019-5545.44908

[13] Chintamaneni, M. and Bhaskar, M. (2012) Biomarkers in Alzheimer's Disease: A Review. ISRN Pharmacology, 2012, Article ID: 984786.

[14] Maccioni, R.B., Farias, G., Morales, I. and Navarrete, L. (2010) The Revitalized Tau Hypothesis on Alzheimer's Disease. Archives of Medical Research, 41, 226-231. http://dx.doi.org/10.1016/j.arcmed.2010.03.007

[15] Metzler, M., Pfeiffer, E., Schulz, S.I. and Dempe, J.S. (2013) Curcumin Uptake and Metabolism. BioFactors, 39, 1420. http://dx.doi.org/10.1002/biof.1042

[16] Indira Priyadarsini, K. (2013) Chemical and Structural Features Influencing the Biological Activity of Curcumin. Current Pharmaceutical Design, 19, 2093-2100.

[17] Aggarwal, B.B., Kumar, A. and Bharti, A.C. (2003) Anticancer Potential of Curcumin: Preclinical and Clinical Studies. Anticancer Research, 23, 363-398.

[18] Menon, V.P. and Sudheer, A.R. (2007) Antioxidant and Anti-Inflammatory Properties of Curcumin. In: Aggarwal, B.B., Surh, Y.-J. and Shishodia, S., Eds., The Molecular Targets and Therapeutic Uses of Curcumin in Health and Disease, Springer US, New York, 105-125. http://dx.doi.org/10.1007/978-0-387-46401-5_3

[19] Xu, X.B., Chen, B. and Liu, W.Y. (2014) Curcumin Inhibits the Invasion of Thyroid Cancer Cells via Down-Regulation of PI3K/Akt Signaling Pathway. Gene, 546, 226-232. http://dx.doi.org/10.1016/j.gene.2014.06.006

[20] Terlikowska, K., Witkowska, A. and Terlikowski, S. (2013) Curcumin in Chemoprevention of Breast Cancer. Postepy Higieny i Medycyny Doswiadczalnej (Online), 68, 571-578.

[21] Pyun, C.W., Kim, J.H., Han, K.H., Hong, G.E. and Lee, C.H. (2014) In Vivo Protective Effects of Dietary Curcumin and Capsaicin against Alcohol-Induced Oxidative Stress. BioFactors, in Press. http://dx.doi.org/10.1002/biof.1172

[22] Zeng, Y., Liu, J., Huang, Z., Pan, X. and Zhang, L. (2014) Effect of Curcumin on Antioxidant Function in the Mice with Acute Alcoholic Liver Injury. Journal of Hygiene Research, 43, 282-285.

[23] Ganguli, M., Chandra, V., Kamboh, M.I., Johnston, J.M., Dodge, H.H., Thelma, B.K., et al. (2000) Apolipoprotein E Polymorphism and Alzheimer Disease: The Indo-US Cross-National Dementia Study. Archives of Neurology, 57, 824830. http://dx.doi.org/10.1001/archneur.57.6.824

[24] Ng, T.P., Chiam, P.C., Lee, T., Chua, H.C., Lim, L. and Kua, E.H. (2006) Curry Consumption and Cognitive Function 
in the Elderly. American Journal of Epidemiology, 164, 898-906. http://dx.doi.org/10.1093/aje/kwj267

[25] Ak, T. and Gülçin, İ. (2008) Antioxidant and Radical Scavenging Properties of Curcumin. Chemico-Biological Interactions, 174, 27-37. http://dx.doi.org/10.1016/j.cbi.2008.05.003

[26] Begum, A.N., Jones, M.R., Lim, G.P., Morihara, T., Kim, P., Heath, D.D., et al. (2008) Curcumin Structure-Function, Bioavailability, and Efficacy in Models of Neuroinflammation and Alzheimer's Disease. Journal of Pharmacology and Experimental Therapeutics, 326, 196-208. http://dx.doi.org/10.1124/jpet.108.137455

[27] Yang, F., Lim, G.P., Begum, A.N., Ubeda, O.J., Simmons, M.R., Ambegaokar, S.S., et al. (2005) Curcumin Inhibits Formation of Amyloid $\beta$ Oligomers and Fibrils, Binds Plaques, and Reduces Amyloid in Vivo. Journal of Biological Chemistry, 280, 5892-5901. http://dx.doi.org/10.1074/jbc.M404751200

[28] Mishra, S. and Palanivelu, K. (2008) The Effect of Curcumin (Turmeric) on Alzheimer's Disease: An Overview. Annals of Indian Academy of Neurology, 11, 13-19. http://dx.doi.org/10.4103/0972-2327.40220

[29] Lin, L.C. and Tsai, T.H. (2011) Curcumin and Its Nano-Formulation: The Kinetics of Tissue Distribution and BloodBrain Barrier Penetration. International Journal of Pharmaceutics, 416, 331-338. http://dx.doi.org/10.1016/j.ijpharm.2011.06.030

[30] Jiang, J., Wang, W., Sun, Y.J., Hu, M., Li, F. and Zhu, D.Y. (2007) Neuroprotective Effect of Curcumin on Focal Cerebral Ischemic Rats by Preventing Blood-Brain Barrier Damage. European Journal of Pharmacology, 561, 54-62. http://dx.doi.org/10.1016/j.ejphar.2006.12.028

[31] Wang, X., Kim, J.R., Lee, S.B., Kim, Y.J., Jung, M.Y., Kwon, H.W. and Ahn, Y.J. (2014) Effects of Curcuminoids Identified in Rhizomes of Curcuma longa on BACE-1 Inhibitory and Behavioral Activity and Lifespan of Alzheimer's Disease Drosophila Models. BMC Complementary and Alternative Medicine, 14, 88. http://dx.doi.org/10.1186/1472-6882-14-88

[32] Deshpande, A., Mina, E., Glabe, C. and Busciglio, J. (2006) Different Conformations of Amyloid $\beta$ Induce Neurotoxicity by Distinct Mechanisms in Human Cortical Neurons. The Journal of Neuroscience, 26, 6011-6018. http://dx.doi.org/10.1523/JNEUROSCI.1189-06.2006

[33] Busciglio, J., Lorenzo, A., Yeh, J. and Yankner, B.A. (1995) Beta-Amyloid Fibrils Induce Tau Phosphorylation and Loss of Microtubule Binding. Neuron, 14, 879-888. http://dx.doi.org/10.1016/0896-6273(95)90232-5

[34] Li, S., Jin, M., Koeglsperger, T., Shepardson, N.E., Shankar, G.M. and Selkoe, D.J. (2011) Soluble A $\beta$ Oligomers Inhibit Long-Term Potentiation through a Mechanism Involving Excessive Activation of Extrasynaptic NR2B-Containing NMDA Receptors. The Journal of Neuroscience, 31, 6627-6638. http://dx.doi.org/10.1523/JNEUROSCI.0203-11.2011

[35] Naslund, J., et al. (2000) Correlation between Elevated Levels of Amyloid Beta-Peptide in the Brain and Cognitive Decline. JAMA, 83, 1571-1577. http://dx.doi.org/10.1001/jama.283.12.1571

[36] Bush, A. and Tanzi, R. (2008) Therapeutics for Alzheimer's Disease Based on the Metal Hypothesis. Neurotherapeutics, 5, 421-432. http://dx.doi.org/10.1016/j.nurt.2008.05.001

[37] Lambracht-Washington, D. and Rosenberg, R.N. (2013) Anti-Amyloid-Beta to Tau-Based Immunization: Developments in Immunotherapy for Alzheimer's Disease. ImmunoTargets and Therapy, 2, 105-114. http://dx.doi.org/10.2147/ITT.S31428

[38] Anastasio, T.J. (2014) Computational Identification of Potential Multitarget Treatments for Ameliorating the Adverse Effects of Amyloid- $\beta$ on Synaptic Plasticity. Frontiers in Pharmacology, 5, 85. http://dx.doi.org/10.3389/fphar.2014.00085

[39] Alzheimer's Association (2008) Experimental Alzheimer Drugs Targeting Beta-Amyloid and the "Amyloid Hypothesis". http://www.alz.org/national/documents/topicsheet betaamyloid.pdf

[40] Lim, G.P., Chu, T., Yang, F., Beech, W., Frautschy, S.A. and Cole, G.M. (2001) The Curry Spice Curcumin Reduces Oxidative Damage and Amyloid Pathology in an Alzheimer Transgenic Mouse. The Journal of Neuroscience, 21, 8370-8377.

[41] Garcia-Alloza, M., Borrelli, L.A., Rozkalne, A., Hyman, B.T. and Bacskai, B.J. (2007) Curcumin Labels Amyloid Pathology in Vivo, Disrupts Existing Plaques, and Partially Restores Distorted Neurites in an Alzheimer Mouse Model. Journal of Neurochemistry, 102, 1095-1104. http://dx.doi.org/10.1111/j.1471-4159.2007.04613.x

[42] Caesar, I., Jonson, M., Nilsson, K.P.R., Thor, S. and Hammarström, P. (2012) Curcumin Promotes A-Beta Fibrillation and Reduces Neurotoxicity in Transgenic Drosophila. PLoS ONE, 7, e31424. http://dx.doi.org/10.1371/journal.pone.0031424

[43] Zhao, L.N., Chiu, S.W., Benoit, J., Chew, L.Y. and Mu, Y. (2012) The Effect of Curcumin on the Stability of A $\beta$ Dimers. The Journal of Physical Chemistry B, 116, 7428-7435. http://dx.doi.org/10.1021/jp3034209

[44] Reinke, A.A. and Gestwicki, J.E. (2007) Structure-Activity Relationships of Amyloid Beta-Aggregation Inhibitors 
Based on Curcumin: Influence of Linker Length and Flexibility. Chemical Biology \& Drug Design, 70, 206-215. http://dx.doi.org/10.1111/j.1747-0285.2007.00557.x

[45] Masuda, Y., Fukuchi, M., Yatagawa, T., Tada, M., Takeda, K., Irie, K., et al. (2011) Solid-State NMR Analysis of Interaction Sites of Curcumin and 42-Residue Amyloid $\beta$-Protein Fibrils. Bioorganic \& Medicinal Chemistry, 19, 59675974. http://dx.doi.org/10.1016/j.bmc.2011.08.052

[46] Fiala, M., Lin, J., Ringman, J., Kermani-Arab, V., Tsao, G., Patel, A., et al. (2005) Ineffective Phagocytosis of Amyloid- $\beta$ by Macrophages of Alzheimer's Disease Patients. Journal of Alzheimer's Disease, 7, 221-232.

[47] Weiner, H.L. and Selkoe, D.J. (2002) Inflammation and Therapeutic Vaccination in CNS Diseases. Nature, 420, 879884. http://dx.doi.org/10.1038/nature01325

[48] Bard, F., et al. (2000) Peripherally Administered Antibodies against Amyloid $\beta$-Peptide Enter the Central Nervous System and Reduce Pathology in a Mouse Model of Alzheimer Disease. Nature Medicine, 6, 916-919. http://dx.doi.org/10.1038/78682

[49] Zhang, L., et al. (2006) Curcuminoids Enhance Amyloid- $\beta$ Uptake by Macrophages of Alzheimer's Disease Patients. Journal of Alzheimer's Disease, 10, 1-7.

[50] Puglielli, L., Tanzi, R.E. and Kovacs, D.M. (2003) Alzheimer's Disease: The Cholesterol Connection. Nature Neuroscience, 6, 345-351. http://dx.doi.org/10.1038/nn0403-345

[51] Regitz, C. and Wenzel, U. (2014) Amyloid-Beta (A $\left.\beta_{1-42}\right)$-Induced Paralysis in Caenorhabditis elegans Is Reduced by Restricted Cholesterol Supply. Neuroscience Letters, 576, 93-96. http://dx.doi.org/10.1016/j.neulet.2014.05.059

[52] Wong, B.X., Hung, Y.H., Bush, A.I. and Duce, J.A. (2014) Metals and Cholesterol: Two Sides of the Same Coin in Alzheimer's Disease Pathology. Frontiers in Aging Neuroscience, 6, 91. http://dx.doi.org/10.3389/fnagi.2014.00091

[53] Popp, J., Lewczuk, P., Kölsch, H., Meichsner, S., Maier, W., Kornhuber, J., et al. (2012) Cholesterol Metabolism Is Associated with Soluble Amyloid Precursor Protein Production in Alzheimer's Disease. Journal of Neurochemistry, 123, 310-316. http://dx.doi.org/10.1111/j.1471-4159.2012.07893.x

[54] Wood, W.G., Li, L., Müller, W.E. and Eckert, G.P. (2014) Cholesterol as a Causative Factor in Alzheimer's Disease: A Debatable Hypothesis. Journal of Neurochemistry, 129, 559-572. http://dx.doi.org/10.1111/jnc.12637

[55] Gamba, P., Testa, G., Sottero, B., Gargiulo, S., Poli, G. and Leonarduzzi, G. (2012) The Link between Altered Cholesterol Metabolism and Alzheimer's Disease. Annals of the New York Academy of Sciences, 1259, 54-64. http://dx.doi.org/10.1111/j.1749-6632.2012.06513.x

[56] Heverin, M., Bogdanovic, N., Lütjohann, D., Bayer, T., Pikuleva, I., Bretillon, L., et al. (2004) Changes in the Levels of Cerebral and Extracerebral Sterols in the Brain of Patients with Alzheimer's Disease. Journal of Lipid Research, 45, 186-193. http://dx.doi.org/10.1194/jlr.M300320-JLR200

[57] Igbavboa, U., Pidcock, J.M., Johnson, L.N., Malo, T.M., Studniski, A.E., Yu, S., et al. (2003) Cholesterol Distribution in the Golgi Complex of DITNC1 Astrocytes Is Differentially Altered by Fresh and Aged Amyloid $\beta$-Peptide-(1-42). Journal of Biological Chemistry, 278, 17150-17157. http://dx.doi.org/10.1074/jbc.M301150200

[58] Maulik, M., Westaway, D., Jhamandas, J.H. and Kar, S. (2013) Role of Cholesterol in APP Metabolism and Its Significance in Alzheimer's Disease Pathogenesis. Molecular Neurobiology, 47, 37-63. http://dx.doi.org/10.1007/s12035-012-8337-y

[59] Beel, A.J., Sakakura, M., Barrett, P.J. and Sanders, C.R. (2010) Direct Binding of Cholesterol to the Amyloid Precursor Protein: An Important Interaction in Lipid-Alzheimer's Disease Relationships? Biochimica et Biophysica Acta (BBA)-Molecular and Cell Biology of Lipids, 1801, 975-982. http://dx.doi.org/10.1016/j.bbalip.2010.03.008

[60] Bodovitz, S. and Klein, W.L. (1996) Cholesterol Modulates-Secretase Cleavage of Amyloid Precursor Protein. Journal of Biological Chemistry, 271, 4436-4440. http://dx.doi.org/10.1074/jbc.271.8.4436

[61] Soni, K.B. and Kuttan, R. (1992) Effect of Oral Curcumin Administration on Serum Peroxides and Cholesterol Levels in Human Volunteers. Indian Journal of Physiology and Pharmacology, 36, 273-273.

[62] Ringman, J.M., Frautschy, S.A., Cole, G.M., Masterman, D.L. and Cummings, J.L. (2005) A Potential Role of the Curry Spice Curcumin in Alzheimer's Disease. Current Alzheimer Research, 2, 131-136. http://dx.doi.org/10.2174/1567205053585882

[63] Sahebkar, A. (2014) A Systematic Review and Meta-Analysis of Randomized Controlled Trials Investigating the Effects of Curcumin on Blood Lipid Levels. Clinical Nutrition, 33, 406-414. http://dx.doi.org/10.1016/j.clnu.2013.09.012

[64] White, A.R., Reyes, R., Mercer, J.F., Camakaris, J., Zheng, H., Bush, A.I., et al. (1999) Copper Levels Are Increased in the Cerebral Cortex and Liver of APP and APLP2 Knockout Mice. Brain Research, 842, 439-444. http://dx.doi.org/10.1016/S0006-8993(99)01861-2

[65] Ahuja, A., Dev, K., Tanwar, R.S. and Tyagi, P.K. (2014) Copper Mediated Neurological Disorder: Visions into Amyotrophic Lateral Sclerosis, Alzheimer and Menkes Disease. Journal of Trace Elements in Medicine and Biology, in Press. 
http://dx.doi.org/10.1016/j.jtemb.2014.05.003

[66] Squitti, R. (2012) Copper Dysfunction in Alzheimer's Disease: From Meta-Analysis of Biochemical Studies to New Insight into Genetics. Journal of Trace Elements in Medicine and Biology, 26, 93-96. http://dx.doi.org/10.1016/j.jtemb.2012.04.012

[67] Brewer, G.J. (2012) Copper Toxicity in Alzheimer's Disease: Cognitive Loss from Ingestion of Inorganic Copper. Journal of Trace Elements in Medicine and Biology, 26, 89-92. http://dx.doi.org/10.1016/j.jtemb.2012.04.019

[68] Angeletti, B., et al. (2005) BACE1 Cytoplasmic Domain Interacts with the Copper Chaperone for Superoxide Dismutase-1 and Binds Copper. Journal of Biological Chemistry, 280, 17930-17937. http://dx.doi.org/10.1074/jbc.M412034200

[69] Sparks, D.L. and Schreurs, B.G. (2003) Trace Amounts of Copper in Water Induce $\beta$-Amyloid Plaques and Learning Deficits in a Rabbit Model of Alzheimer's Disease. Proceedings of the National Academy of Sciences of the United States of America, 100, 11065-11069. http://dx.doi.org/10.1073/pnas. 1832769100

[70] Curtain, C.C., Ali, F.E., Smith, D.G., Bush, A.I., Masters, C.L. and Barnham, K.J. (2003) Metal Ions, pH, and Cholesterol Regulate the Interactions of Alzheimer's Disease Amyloid- $\beta$ Peptide with Membrane Lipid. Journal of Biological Chemistry, 278, 2977-2982. http://dx.doi.org/10.1074/jbc.M205455200

[71] Eskici, G. and Axelsen, P.H. (2012) Copper and Oxidative Stress in the Pathogenesis of Alzheimer's Disease. Biochemistry, 51, 6289-6311. http://dx.doi.org/10.1021/bi3006169

[72] Meloni, G., Sonois, V., Delaine, T., Guilloreau, L., Gillet, A., Teissié, J., et al. (2008) Metal Swap between $\mathrm{Zn}_{7}-\mathrm{Me}$ tallothionein-3 and Amyloid- $\beta$-Cu Protects against Amyloid- $\beta$ Toxicity. Nature Chemical Biology, 4, 366-372. http://dx.doi.org/10.1038/nchembio.89

[73] Hung, Y.H., Robb, E.L., Volitakis, I., Ho, M., Evin, G., Li, Q.X., et al. (2009) Paradoxical Condensation of Copper with Elevated Beta-Amyloid in Lipid Rafts under Cellular Copper Deficiency Conditions: Implications for Alzheimer Disease. The Journal of Biological Chemistry, 284, 21899-21907. http://dx.doi.org/10.1074/jbc.M109.019521

[74] Singh, I., Sagare, A.P., Coma, M., Perlmutter, D., Gelein, R., Bell, R.D., et al. (2013) Low Levels of Copper Disrupt Brain Amyloid- $\beta$ Homeostasis by Altering Its Production and Clearance. Proceedings of the National Academy of Sciences of the United States of America, 110, 14771-14776. http://dx.doi.org/10.1073/pnas.1302212110

[75] Huang, X., et al. (1999) The A $\beta$ Peptide of Alzheimer's Disease Directly Produces Hydrogen Peroxide through Metal Ion Reduction. Biochemistry, 38, 7609-7616. http://dx.doi.org/10.1021/bi990438f

[76] Berridge, M.J. (2010) Calcium Hypothesis of Alzheimer's Disease. Pflügers Archiv-European Journal of Physiology, 459, 441-449. http://dx.doi.org/10.1007/s00424-009-0736-1

[77] Berridge, M.J. (2013) Dysregulation of Neural Calcium Signaling in Alzheimer Disease, Bipolar Disorder and Schizophrenia. Prion, 7, 2-13. http://dx.doi.org/10.4161/pri.21767

[78] Cherny, R.A., Atwood, C.S., Xilinas, M.E., Gray, D.N., Jones, W.D., McLean, C.A., et al. (2001) Treatment with a Copper-Zinc Chelator Markedly and Rapidly Inhibits $\beta$-Amyloid Accumulation in Alzheimer's Disease Transgenic Mice. Neuron, 30, 665-676. http://dx.doi.org/10.1016/S0896-6273(01)00317-8

[79] Noël, S., Perez, F., Pedersen, J.T., Alies, B., Ladeira, S., Sayen, S., et al. (2012) A New Water-Soluble Cu(II) Chelator That Retrieves $\mathrm{Cu}$ from $\mathrm{Cu}$ (Amyloid- $\beta$ ) Species, Stops Associated ROS Production and Prevents $\mathrm{Cu}(\mathrm{II})-\mathrm{Induced} \mathrm{A} \beta$ Aggregation. Journal of Inorganic Biochemistry, 117, 322-325. http://dx.doi.org/10.1016/i.jinorgbio.2012.05.016

[80] Geng, J., Li, M., Wu, L., Ren, J. and Qu, X. (2012) Liberation of Copper from Amyloid Plaques: Making a Risk Factor Useful for Alzheimer's Disease Treatment. Journal of Medicinal Chemistry, 55, 9146-9155. http://dx.doi.org/10.1021/jm3003813

[81] Matlack, K.E., Tardiff, D.F., Narayan, P., Hamamichi, S., Caldwell, K.A., Caldwell, G.A. and Lindquist, S. (2014) Clioquinol Promotes the Degradation of Metal-Dependent Amyloid- $\beta$ (A $\beta$ ) Oligomers to Restore Endocytosis and Ameliorate A $\beta$ Toxicity. Proceedings of the National Academy of Sciences of the United States of America, 111, 40134018. http://dx.doi.org/10.1073/pnas.1402228111

[82] Hua, H., Munter, L., Harmeier, A., Georgiev, O., Multhaup, G. and Schaffner, W. (2011) Toxicity of Alzheimer's Disease-Associated Abeta Peptide Is Ameliorated in a Drosophila Model by Tight Control of Zinc and Copper Availability. Biological Chemistry, 392, 919-926. http://dx.doi.org/10.1515/BC.2011.084

[83] Baum, L. and Ng, A. (2004) Curcumin Interaction with Copper and Iron Suggests One Possible Mechanism of Action in Alzheimer's Disease Animal Models. Journal of Alzheimer's Disease, 6, 367-377.

[84] Picciano, A.L. and Vaden, T.D. (2013) Complexation between Cu(II) and Curcumin in the Presence of Two Different Segments of Amyloid $\beta$. Biophysical Chemistry, 184, 62-67. http://dx.doi.org/10.1016/j.bpc.2013.09.004

[85] Huang, H.C., Lin, C.J., Liu, W.J., Jiang, R.R. and Jiang, Z.F. (2011) Dual Effects of Curcumin on Neuronal Oxidative Stress in the Presence of $\mathrm{Cu}(\mathrm{II})$. Food and Chemical Toxicology, 49, 1578-1583. 
http://dx.doi.org/10.1016/j.fct.2011.04.004

[86] Park, S.Y., Kim, H.S., Cho, E.K., Kwon, B.Y., Phark, S., Hwang, K.W. and Sul, D. (2008) Curcumin Protected PC12 Cells against Beta-Amyloid-Induced Toxicity through the Inhibition of Oxidative Damage and Tau Hyperphosphorylation. Food and Chemical Toxicology, 46, 2881-2887. http://dx.doi.org/10.1016/j.fct.2008.05.030

[87] Bayer, T.A., Schäfer, S., Simons, A., Kemmling, A., Kamer, T., Tepests, R., et al. (2003) Dietary Cu Stabilizes Brain Superoxide Dismutase 1 Activity and Reduces Amyloid A $\beta$ Production in APP23 Transgenic Mice. Proceedings of the National Academy of Sciences of the United States of America, 100, 14187-14192. http://dx.doi.org/10.1073/pnas.2332818100

[88] Klevay, L.M. (2008) Alzheimer's Disease as Copper Deficiency. Medical Hypotheses, 70, 802-807. http://dx.doi.org/10.1016/j.mehy.2007.04.051

[89] Cater, M., McInnes, K., Li, Q., Volitakis, I., La Fontaine, S., Mercer, J. and Bush, A. (2008) Intracellular Copper Deficiency Increases Amyloid-Beta Secretion by Diverse Mechanisms. Biochemical Journal, 412, 141-152. http://dx.doi.org/10.1042/BJ20080103

[90] Smale, G., Nichols, N.R., Brady, D.R., Finch, C.E. and Horton, W.E. (1995) Evidence for Apoptotic Cell Death in Alzheimer's Disease. Experimental Neurology, 133, 225-230. http://dx.doi.org/10.1006/exnr.1995.1025

[91] Suo, Z., Tan, J., Placzek, A., Crawford, F., Fang, C. and Mullan, M. (1998) Alzheimer's $\beta$-Amyloid Peptides Induce Inflammatory Cascade in Human Vascular Cells: The Roles of Cytokines and CD40. Brain Research, 807, 110-117. http://dx.doi.org/10.1016/S0006-8993(98)00780-X

[92] Del Bo, R., Angeretti, N., Lucca, E., De Simoni, M.G. and Forloni, G. (1995) Reciprocal Control of Inflammatory Cytokines, IL-1 and IL-6, and $\beta$-Amyloid Production in Cultures. Neuroscience Letters, 188, 70-74. http://dx.doi.org/10.1016/0304-3940(95)11384-9

[93] McGeer, P.L., Schulzer, M. and McGeer, E.G. (1996) Arthritis and Anti-Inflammatory Agents as Possible Protective factors for Alzheimer's Disease A Review of 17 Epidemiologic Studies. Neurology, 47, 425-432. http://dx.doi.org/10.1212/WNL.47.2.425

[94] Griffin, W.S.T., Sheng, J.G., Roberts, G.W. and Mrak, R.E. (1995) Interleukin-1 Expression in Different Plaque Types in Alzheimer's Disease: Significance in Plaque Evalution. Journal of Neuropathology \& Experimental Neurology, 54, 276-281. http://dx.doi.org/10.1097/00005072-199503000-00014

[95] Buxbaum, J.D., Oishi, M., Chen, H.I., Pinkas-Kramarski, R., Jaffe, E.A., Gandy, S.E. and Greengard, P. (1992) Cholinergic Agonists and Interleukin 1 Regulate Processing and Secretion of the Alzheimer Beta/A4 Amyloid Protein Precursor. Proceedings of the National Academy of Sciences of the United States of America, 89, 10075-10078. http://dx.doi.org/10.1073/pnas.89.21.10075

[96] Goldgaber, D., Harris, H.W., Hla, T., Maciag, T., Donnelly, R.J., Jacobsen, J.S., et al. (1989) Interleukin 1 Regulates Synthesis of Amyloid Beta-Protein Precursor mRNA in Human Endothelial Cells. Proceedings of the National Academy of Sciences of the United States of America, 86, 7606-7610. http://dx.doi.org/10.1073/pnas.86.19.7606

[97] Trepanier, C.H. and Milgram, N.W. (2010) Neuroinflammation in Alzheimer's Disease: Are NSAIDs and Selective COX-2 Inhibitors the Next Line of Therapy? Journal of Alzheimer's Disease, 21, 1089-1099.

[98] Kalinski, T., Sel, S., Hütten, H., Röpke, M., Roessner, A. and Nass, N. (2014) Curcumin Blocks Interleukin-1 Signaling in Chondrosarcoma Cells. PLoS ONE, 9, e99296. http://dx.doi.org/10.1371/journal.pone.0099296

[99] Ahmed, T. and Gilani, A.H. (2011) A Comparative Study of Curcuminoids to Measure Their Effect on Inflammatory and Apoptotic Gene Expression in an A $\beta$ plus Ibotenic Acid-Infused Rat Model of Alzheimer's Disease. Brain Research, 1400, 1-18. http://dx.doi.org/10.1016/j.brainres.2011.05.022

[100] Qin, X.Y., Cheng, Y. and Yu, L.C. (2010) Potential Protection of Curcumin against Intracellular Amyloid $\beta$-Induced Toxicity in Cultured Rat Prefrontal Cortical Neurons. Neuroscience Letters, 480, 21-24. http://dx.doi.org/10.1016/j.neulet.2010.05.062

[101] Allan Butterfield, D., Castegna, A., Lauderback, C.M. and Drake, J. (2002) Evidence That Amyloid Beta-Peptide-Induced Lipid Peroxidation and Its Sequelae in Alzheimer's Disease Brain Contribute to Neuronal Death. Neurobiology of Aging, 23, 655-664. http://dx.doi.org/10.1016/S0197-4580(01)00340-2

[102] Butterfield, D.A. and Lauderback, C.M. (2002) Lipid Peroxidation and Protein Oxidation in Alzheimer's Disease Brain: Potential Causes and Consequences Involving Amyloid $\beta$-Peptide-Associated Free Radical Oxidative Stress. Free Radical Biology and Medicine, 32, 1050-1060. http://dx.doi.org/10.1016/S0891-5849(02)00794-3

[103] Behl, C. (1999) Alzheimer's Disease and Oxidative Stress: Implications for Novel Therapeutic Approaches. Progress in Neurobiology, 57, 301-323. http://dx.doi.org/10.1016/S0301-0082(98)00055-0

[104] Butterfield, D.A., Swomley, A.M. and Sultana, R. (2013) Amyloid $\beta$-Peptide (1-42)-Induced Oxidative Stress in Alzheimer Disease: Importance in Disease Pathogenesis and Progression. Antioxidants \& Redox Signaling, 19, 823-835. http://dx.doi.org/10.1089/ars.2012.5027 
[105] Allan Butterfield, D. (2002) Amyloid $\beta$-Peptide (1-42)-Induced Oxidative Stress and Neurotoxicity: Implications for Neurodegeneration in Alzheimer's Disease Brain. A Review. Free Radical Research, 36, 1307-1313. http://dx.doi.org/10.1080/1071576021000049890

[106] Jena, S., Dandapat, J. and Chainy, G.B.N. (2013) Curcumin Differentially Regulates the Expression of Superoxide Dismutase in Cerebral Cortex and Cerebellum of 1-Thyroxine (T4)-Induced Hyperthyroid Rat Brain. Neurological Sciences, 34, 505-510. http://dx.doi.org/10.1007/s10072-012-1084-Z

[107] Huang, H.C., Chang, P., Dai, X.L. and Jiang, Z.F. (2012) Protective Effects of Curcumin on Amyloid- $\beta$-Induced Neuronal Oxidative Damage. Neurochemical Research, 37, 1584-1597. http://dx.doi.org/10.1007/s11064-012-0754-9

[108] Cassimeris, L. and Spittle, C. (2001) Regulation of Microtubule-Associated Proteins. International Review of Cytology, 210, 163-226. http://dx.doi.org/10.1016/S0074-7696(01)10006-9

[109] Wittmann, C.W., Wszolek, M.F., Shulman, J.M., Salvaterra, P.M., Lewis, J., Hutton, M. and Feany, M.B. (2001) Tauopathy in Drosophila: Neurodegeneration without Neurofibrillary Tangles. Science, 293, 711-714. http://dx.doi.org/10.1126/science.1062382

[110] Iba, M., Guo, J.L., McBride, J.D., Zhang, B., Trojanowski, J.Q. and Lee, V.M.Y. (2013) Synthetic Tau Fibrils Mediate Transmission of Neurofibrillary Tangles in a Transgenic Mouse Model of Alzheimer's-Like Tauopathy. The Journal of Neuroscience, 33, 1024-1037. http://dx.doi.org/10.1523/JNEUROSCI.2642-12.2013

[111] Ittner, L.M. and Götz, J. (2010) Amyloid- $\beta$ and Tau-A Toxic pas de Deux in Alzheimer's Disease. Nature Reviews. Neuroscience, 12, 65-72.

[112] Rapoport, M., Dawson, H.N., Binder, L.I., Vitek, M.P. and Ferreira, A. (2002) Tau Is Essential to $\beta$-Amyloid-Induced Neurotoxicity. Proceedings of the National Academy of Sciences of the United States of America, 99, 6364-6369. http://dx.doi.org/10.1073/pnas.092136199

[113] Bloom, G.S. (2014) Amyloid- $\beta$ and Tau: The Trigger and Bullet in Alzheimer Disease Pathogenesis. JAMA Neurology, 71, 505-508. http://dx.doi.org/10.1001/jamaneurol.2013.5847

[114] Medina, M. and Avila, J. (2014) New Perspectives on the Role of Tau in Alzheimer's Disease. Implications for Therapy. Biochemical Pharmacology, 88, 540-547. http://dx.doi.org/10.1016/j.bcp.2014.01.013

[115] Mutsuga, M., Chambers, J.K., Uchida, K., Tei, M., Makibuchi, T., Mizorogi, T., et al. (2012) Binding of Curcumin to Senile Plaques and Cerebral Amyloid Angiopathy in the Aged Brain of Various Animals and to Neurofibrillary Tangles in Alzheimer's Brain. The Journal of Veterinary Medical Science, 74, 51-57. http://dx.doi.org/10.1292/jvms.11-0307

[116] Villaflores, O.B., Chen, Y.J., Chen, C.P., Yeh, J.M. and Wu, T.Y. (2012) Effects of Curcumin and Demethoxycurcumin on Amyloid- $\beta$ Precursor and Tau Proteins through the Internal Ribosome Entry Sites: A Potential Therapeutic for Alzheimer's Disease. Taiwanese Journal of Obstetrics and Gynecology, 51, 554-564. http://dx.doi.org/10.1016/j.tjog.2012.09.010

[117] Ma, Q.L., Zuo, X., Yang, F., Ubeda, O.J., Gant, D.J., Alaverdyan, M., et al. (2013) Curcumin Suppresses Soluble Tau Dimers and Corrects Molecular Chaperone, Synaptic, and Behavioral Deficits in Aged Human Tau Transgenic Mice. Journal of Biological Chemistry, 288, 4056-4065. http://dx.doi.org/10.1074/jbc.M112.393751

[118] Belkacemi, A., Doggui, S., Dao, L. and Ramassamy, C. (2011) Challenges Associated with Curcumin Therapy in Alzheimer Disease. Expert Reviews in Molecular Medicine, 13, e34. http://dx.doi.org/10.1017/S1462399411002055

[119] Prasad, S., Tyagi, A.K. and Aggarwal, B.B. (2014) Recent Developments in Delivery, Bioavailability, Absorption and Metabolism of Curcumin: The Golden Pigment from Golden Spice. Cancer Research and Treatment, 46, 2-18. http://dx.doi.org/10.4143/crt.2014.46.1.2

[120] Yang, K.Y., Lin, L.C., Tseng, T.Y., Wang, S.C. and Tsai, T.H. (2007) Oral Bioavailability of Curcumin in Rat and the Herbal Analysis from Curcuma longa by LC-MS/MS. Journal of Chromatography B, 853, 183-189. http://dx.doi.org/10.1016/j.jchromb.2007.03.010

[121] Jang, D.J., Kim, S.T., Oh, E. and Lee, K. (2014) Enhanced Oral Bioavailability and Antiasthmatic Efficacy of Curcumin Using Redispersible Dry Emulsion. Bio-Medical Materials and Engineering, 24, 917-930.

[122] Shelma, R. and Sharma, C.P. (2013) In Vitro and in Vivo Evaluation of Curcumin Loaded Lauroyl Sulphated Chitosan for Enhancing Oral Bioavailability. Carbohydrate Polymers, 95, 441-448. http://dx.doi.org/10.1016/j.carbpol.2013.02.029

[123] Li, C., Zhang, Y., Su, T., Feng, L., Long, Y. and Chen, Z. (2012) Silica-Coated Flexible Liposomes as a Nanohybrid Delivery System for Enhanced Oral Bioavailability of Curcumin. International Journal of Nanomedicine, 7, 5995-6002. http://dx.doi.org/10.2147/IJN.S38043

[124] Holder, G.M., Plummer, J.L. and Ryan, A.J. (1978) The Metabolism and Excretion of Curcumin (1,7-Bis-(4-hydroxy3-methoxyphenyl)-1,6-heptadiene-3,5-dione) in the Rat. Xenobiotica, 8, 761-768.

http://dx.doi.org/10.3109/00498257809069589 
[125] Pan, M.H., Huang, T.M. and Lin, J.K. (1999) Biotransformation of Curcumin through Reduction and Glucuronidation in Mice. Drug Metabolism and Disposition, 27, 486-494.

[126] Ireson, C., Orr, S., Jones, D.J., Verschoyle, R., Lim, C.K., Luo, J.L., et al. (2001) Char-Acterization of Metabolites of the Chemopreventive Agent Curcumin in Human and Rat Hepatocytes and in the Rat in Vivo, and Evaluation of Their Ability to Inhibit Phorbol Ester-Induced Prostaglandin E2 Production. Cancer Research, 61, 1058-1064.

[127] Pan, M.H., Lin-Shiau, S.Y. and Lin, J.K. (2000) Comparative Studies on the Suppression of Nitric Oxide Synthase by Curcumin and Its Hydrogenated Metabolites through Down-Regulation of IkappaB Kinase and NFkappaB Activation in Macrophages. Biochemical Pharmacology, 60, 1665-1676. http://dx.doi.org/10.1016/S0006-2952(00)00489-5

[128] Baum, L., Lam, C.W.K., Cheung, S.K.K., Kwok, T., Lui, V., Tsoh, J., et al. (2008) Six-Month Randomized, Placebo-Controlled, Double-Blind, Pilot Clinical Trial of Curcumin in Patients with Alzheimer Disease. Journal of Clinical Psychopharmacology, 28, 110-113. http://dx.doi.org/10.1097/jcp.0b013e318160862c

[129] Ringman, J.M., Frautschy, S.A., Teng, E., Begum, A.N., Bardens, J., Beigi, M., et al. (2012) Oral Curcumin for Alzheimer's Disease: Tolerability and Efficacy in a 24-Week Randomized, Double Blind, Placebo-Controlled Study. Alzheimer's Research \& Therapy, 4, 43-43. http://dx.doi.org/10.1186/alzrt146

[130] Baum, L., Cheung, S.K., Mok, V.C., Lam, L.C., Leung, V.P., Hui, E., et al. (2007) Curcumin Effects on Blood Lipid Profile in a 6-Month Human Study. Pharmacological Research, 56, 509-514.

http://dx.doi.org/10.1016/j.phrs.2007.09.013 
Scientific Research Publishing (SCIRP) is one of the largest Open Access journal publishers. It is currently publishing more than 200 open access, online, peer-reviewed journals covering a wide range of academic disciplines. SCIRP serves the worldwide academic communities and contributes to the progress and application of science with its publication.

Other selected journals from SCIRP are listed as below. Submit your manuscript to us via either submit@scirp.org or Online Submission Portal.
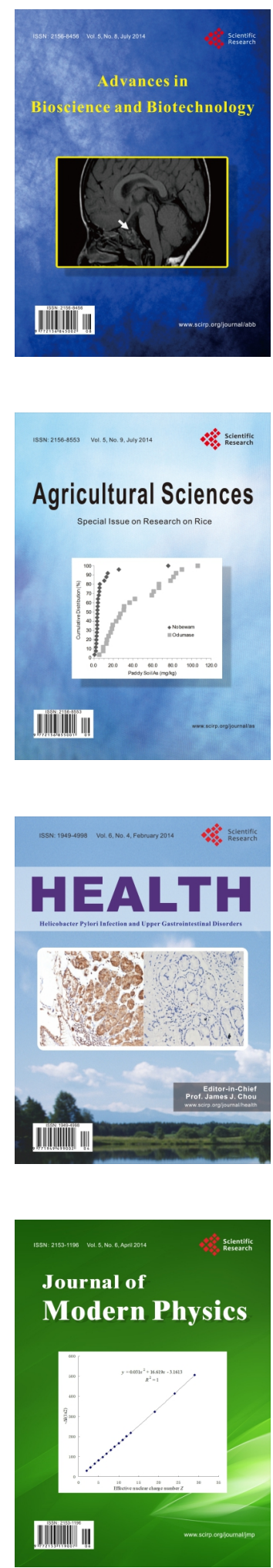
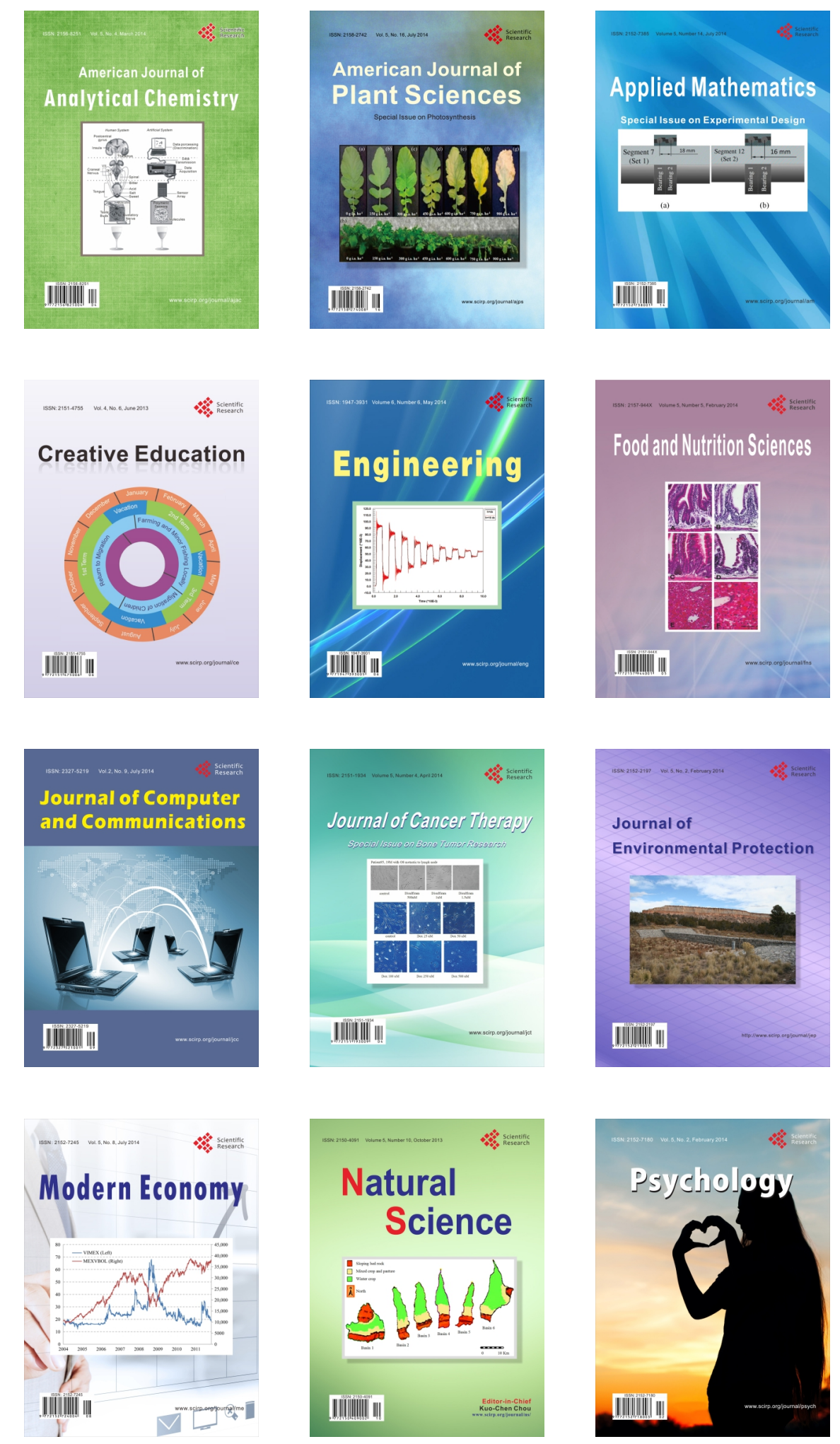